\title{
A new model for Kuroko-type deposits of Japan
}

From the Archean to the present, Kuroko-type massive sulfide deposits have been formed repeatedly on the sea floor in various island arcs. Discoveries of sea-floor hydrothermal deposits in the OKinawa Trough and in the Izu-Bonin arc of the northwestern Pacific Ocean have shed new light on the genesis of their fossil analogs. We are able now to assess the proposed models of the generation of Kuroko deposits by combining information on present-day and ancient deposits. Several lines of evidence suggest that acidic magma emplaced at a high level in the Earth's crust is inevitable as the source of metals and sulfur in the Kuroko deposits. However, metals like lead could be supplied partially from the wall rock as a result of leaching by downward-circulating seawater.

\section{Introduction}

$\mathrm{O}_{\text {ne of the hot controversies concerning the genesis of Kuroko-type }}$ deposits found on the Japanese islands of Honshu and Hokkaido is their source of metal. Hydrogen and oxygen isotopic studies (for example. Pisutha-Amond and Ohmoto. 1983) indicate that a pore fluid of seawater origin played an important role in Kuroko mineralization. The development of the huge volume of alteration halos in the wall rock indicates that a metal-leaching theory is plausible to explain the genesis of Kuroko deposits.

However, newer experimental studies on the partition of base metals between coexisting acidic melts and aqueous fluids indicate that the magma that fed the footwall felsic volcanic rocks of Kuroko deposits would have had a large potential for discharging the metalrich magmatic fluids that formed the Kuroko deposits (Urabe, 1985 , 1987a, b; Nakano and Urabe, 1989).

The purpose of this paper is to reevaluate the geological and geochemical data on the Kuroko deposits in order to outline their genesis on the basis of the latest information available. This information has been obtained through research on Kuroko-type massive sulfide mineralization found in the backarc environment of the Okinawa Trough and the Izu-Bonin arc in the northwestern Pacific Ocean (fig. 1) and through research on the aborted mid-oceanic ridge in the northeastern Pacific.

\section{Geological setting of Kuroko deposits}

The Kuroko deposits in Japan are located in the "Green Tuff" region, which is a 1,500 -km-long backarc trough in the northeastern Japan arc of Miocene age (fig. 1). The opening of a marginal sea (the Sea of Japan) that separated the island arc from the Eurasian conti- nent occurred in the period of 21-14 Ma (Otofuji and others, 1985). The northeastern Japan arc itself also underwent multiple rifting during a tensional tectonic regime. Yamaji (1990) indicated that the rifting started about 3 million years after the initiation of the opening of the Sea of Japan at $18 \mathrm{Ma}$ and ended at $15 \mathrm{Ma}$. The rifting activity peaked between 16 and $15 \mathrm{Ma}$, and $1-3 \mathrm{~km}$ of vertical displacement is estimated to have occurred over 1 million years. Intensive bimodal volcanism of rhyolitic and basaltic composition took place within the rift and was related to the thinning of the Earth's crust at that time. Noteworthy is the fact that similar tectonic and volcanic phenomena are occurring now in the Izu-Bonin arc. Barite-silica chimneys, which are analogous to the hematitic chert of the Kuroko deposits. are found in a backarc basin called the Sumisu rift (Urabe and Kusakabe, 1990).

The Hokuroku basin (fig. 2) is a volcano-sedimentary basin that developed within the rift graben and is designated as the most important Kuroko ore field in Japan. Kuroko deposits of 1-10 million tons of ore reserves are found in this basin, such as Kosaka, Fukazawa, Shakanai, and Matsumine. The total amount of ore in this district is estimated to be approximately 140 million tons, the average ore grade being 1.6 percent copper $(\mathrm{Cu}), 3.0$ percent zinc $(\mathrm{Zn})$, and 0.8 percent lead $(\mathrm{Pb})$ (Tanimura and others. 1983).

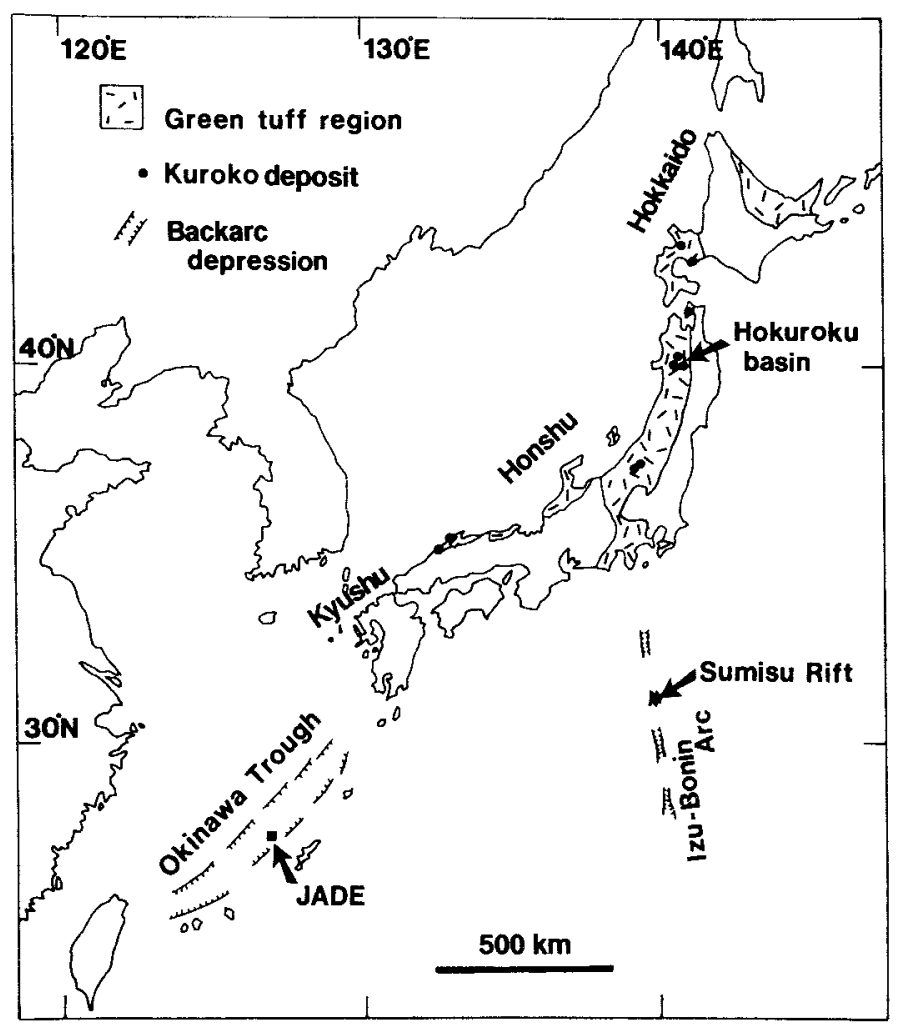

Figure 1.-Distribution of Kuroko deposits and their present-day analogs in the Okinawa Trough (JADE site) and in the backarc environment of the Izu-Bonin arc (Sumisu rift). 


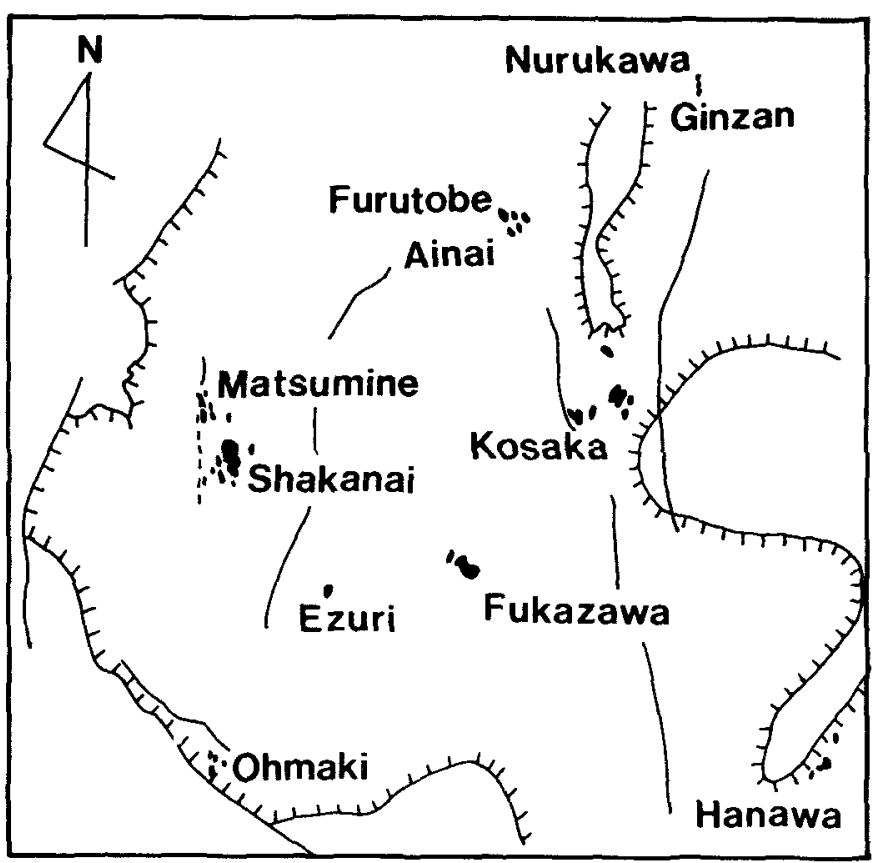

$100 \mathrm{~km}$

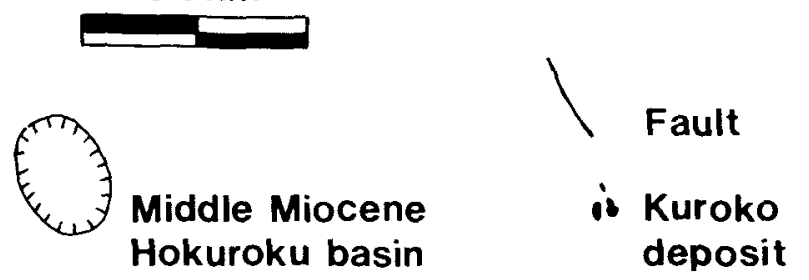

Figure 2.-Distribution of Kuroko deposits in the Hokuroku basin of northeastern Japan (see fig. 1 for location).

An intimate relationship between magmatism and the Kuroko mineralization in the Hokuroku basin has been pointed out by many workers. The initial phase of volcanism began at approximately 40 Ma in a broad area of northeastern Japan. Volcanic products of this phase are dominated by andesite and a small amount of calc-alkaline basalt and rhyolite. Some of the andesitic tuff units have a welded texture and are considered to be subaerial deposits. The second phase of volcanism is characterized by its bimodal nature. Tholeiite basalt and calc-alkaline rhyolite were erupted during the period from 16 to 12 Ma contemporaneous with the active rifting.

\section{Metal-leaching model}

Well-developed alteration halos are observed around the Kuroko deposits, both within the footwall and hanging wall felsic volcanic rocks. Date and others (1983) divided the alteration halo of the Fukazawa deposits into three zones on the basis of the alteration mineral assemblages. Going from the core to the margin, these are the sericite-magnesian chlorite zone $(1.5 \times 3 \mathrm{~km}$ across $)$, the montmorillonite zone (1-3 km wide), and the peripheral zeolite zone.

Ohmoto and others (1983) used the Fukazawa deposits as the field model for the mass balance calculation of metal leaching from the footwall alteration halo. Approximately one-third of the footwall felsic volcanic rocks in the sericite-chlorite zone show $\mathrm{Zn}$ contents less than $40 \mathrm{ppm}$, whereas the average $\mathrm{Zn}$ content of the footwall felsic volcanic rocks in the zeolite zone is $79 \mathrm{ppm}$. On the basis of these $\mathrm{Zn}$ contents in the footwall rock. Ohmoto and others (1983) computed that if the footwall rocks lost an average of $10 \mathrm{ppm} \mathrm{Zn}$ during interaction with downward-circulating seawater, $1 \times 10^{11}$ tons of rocks would be required to provide $1 \times 10^{6}$ tons of $\mathrm{Zn}$ to an ore-forming system. The rock volume needed corresponds to an area of the combined sericite-chlorite and montmorillonite zones $(4 \times 4$ $\mathrm{km}$ ) to a depth of $2.5 \mathrm{~km}$.

\section{Magmatic hydrothermal model}

A detailed examination of the volcanic succession of the Kuroko deposits indicates that the Kuroko mineralization was not the result of a unique event. Instead, it was triggered repeatedly by the eruption of lithic tuff breccia or by the extrusion of rhyolite lava domes in in individual volcanic center (Urabe, 1987a).

The acidic magma related to Kuroko mineralization probab!s was favorable for the generation of ore-forming fluid. Experimental results on the partition of base metals between coexisting granitic melt and aqueous fluid indicate that the metals are strongly partitioned toward the fluid phase (magmatic fluid) if a chlorine-rich fluid is released from the aluminous melt under low confining pressures (Urabe, 1985, 1987b). Acidic magma bodies related to the formation of Kuroko deposits satisfy these requirements. For example, altered breccias of acidic plutonic rocks, which are found in breccia dikes at the Fukazawa deposits, have a porphyritic texture indicating their emplacement at a shallow level of the crust. Besides, the footwail dacite and rhyolite of Kuroko deposits are classified as slightly aluminous, whereas hanging wall dacite and rhyolite are slightiy alkaline (Urabe, 1987a).

\section{Source of ore metals of Kuroko deposits}

\section{Approach from lead isotopic compositions}

The lead isotopic compositions of volcanic rocks of middle Miocene age are less radiogenic than those of basement rocks (phyllites. cherts, and minor sandstone) in the Hokuroku basin (fig. 3). The lead isotopic compositions of the upper part of the massive sulfide ore (black ore) of Kuroko deposits are more radiogenic than those of the lower part of the massive sulfide ore (yellow ore; Fehn and others. 1983). These data indicate that the origin of lead in the yellow ore was different from the origin of lead in the black ore. On the basis if these data, Fehn and others (1983) considered the yellow ore to have had a greater volcanic lead component than the black ore had.

The difference in lead isotopic compositions between the yellow ore and black ore seems to discount a pure magmatic hydrothermal model, such as the one in which Urabe (1987) stressed that all the base metal in the Kuroko deposits came directly from the felsic igneous magma. At first glance, the lead isotopic data seem to support this metal-leaching model (fig. 4). In this model, Ohmoto and others (1983) believed that the Kuroko ore-forming system started during the diagenetic stage, when pore fluids interacted with the middle Miocene felsic volcanic rocks and formed disseminated gypsum. The system was heated by intrusive rock to form black ore at temperatures of 150 to $300{ }^{\circ} \mathrm{C}$ and yellow ore at more than $300{ }^{\circ} \mathrm{C}$. The position of the isotherms during the black ore stage must have been lower than during the yellow ore stage. In the black ore stage, $a$ 

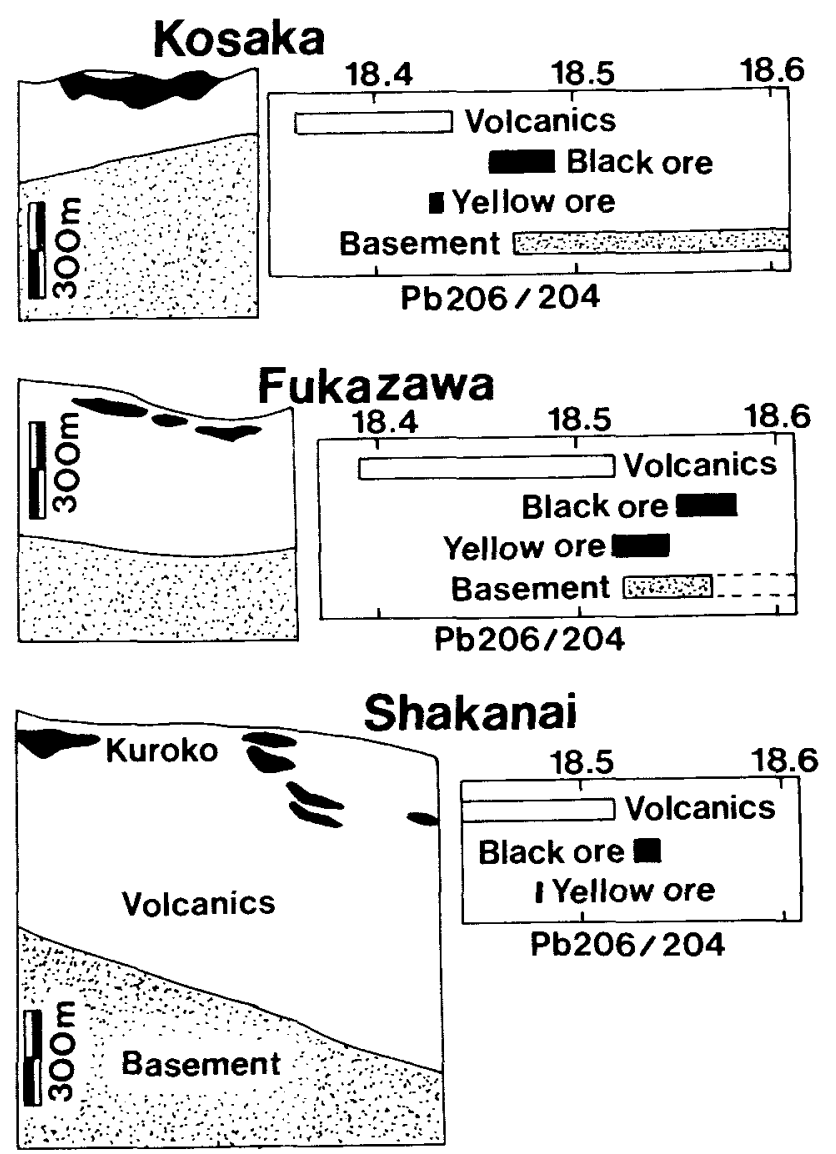

Figure 3.-Schematic cross sections of Kosaka, Fukazawa, and Shakanai deposits and lead isotopic compositions $\left({ }^{206} \mathrm{~Pb} /{ }^{204} \mathrm{~Pb}\right)$ of these Kuroko deposits (data after Fehn and others, 1983). larger amount of lead was mobilized from basement rocks. Therefore, black ore should contain more radiogenic lead from the lower basement formation than yellow ore does (fig. 4).

However, the metal-leaching model presents a serious contradiction if we consider the base metal contents of the middle Miocene volcanic rocks and the basement rocks (phyllites, cherts, and sandstones). The unaltered middle Miocene volcanic rocks contain $8 \mathrm{ppm}$ $\mathrm{Cu}$ or less, whereas the basement rocks possess $20-70 \mathrm{ppm} \mathrm{Cu}$. The lead isotopic compositions suggest that the position of the isotherms during the black ore stage must have been lower than they were during the yellow ore stage. However, this would indicate that the pore fluids must have moved in the $\mathrm{Cu}$-poor volcanic rocks only during the yellow ore stage (fig. 4).

Furthermore, based on the metal-leaching model, we would expect the Kosaka deposits to have a higher $\mathrm{Cu} / \mathrm{Zn}$ ratio than those ratios of the Shakanai and Fukazawa deposits because the basement rocks lie at shallower levels under the Kosaka deposits than they do under the Shakanai and Fukazawa deposits (fig. 3). However, a positive correlation is not observed between $\mathrm{Cu} / \mathrm{Zn}$ ratios and the thickness of the middle Miocene volcanic rocks at the Kosaka, Fukazawa, and Shakanai deposits.

\section{Origin of sulfur and ore fluids}

\section{Approach from sulfur, hydrogen, and oxygen isotopic data}

The most noticeable characteristic of the Kuroko deposits is the remarkable homogeneity of their sulfur isotopic compositions. The delta ${ }^{34} \mathrm{~S}$ values of pyrite, chalcopyrite, and sphalerite are mostly between 2 and $8 \%$ (Kajiwara, 1971). These values are very similar to sulfur isotopic values of the volcanic rocks in the Hokuroku basin (Ishihara and Sasaki, 1978), which indicates that magmatic sulfur could be the major source of the Kuroko sulfur.

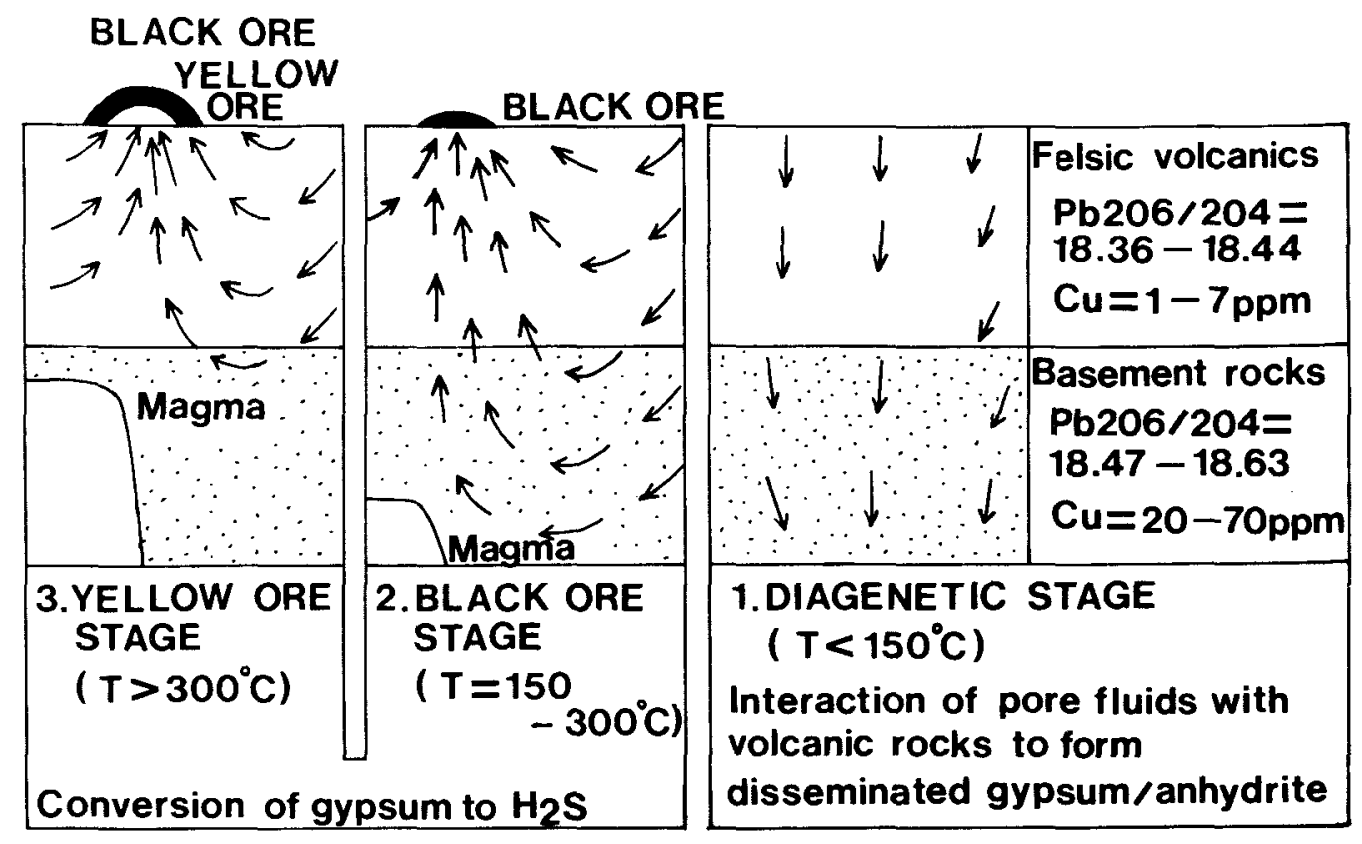

Figure 4.-The metal-leaching model based on the geochemical data in Kosaka deposits. Abbreviation: $T$, temperature. 
In the metal-leaching model, Ohmoto and others (1983) proposed that the Kuroko ore fluids had obtained most of their sulfur from disseminated gypsum and anhydrite, which had formed through the interaction of the pore fluids (seawater) and volcanic rocks during the diagenetic and early hydrothermal stages at temperatures of less than $150^{\circ} \mathrm{C}$ (fig. 4). Some of the sulfate ions derived from anhydrite were reduced to form $\mathrm{H}_{2} \mathrm{~S}$ through reactions with iron and organic carbon in the country rocks at elevated temperatures. At temperatures greater than $300{ }^{\circ} \mathrm{C}$, fluids also acquired some sulfur through the dissolution of pyrite in the volcanic rocks. However, the sulfur content of the fresh volcanic rocks is very low (Nakajima and Sasaki, 1985), and thus the contribution of the igneous pyrite from the volcanic wall rock would be negligible.

Pisutha-Arnond and Ohmoto (1983) showed that the ranges of the delta $D$ values and ${ }^{18} 0$ values of Kuroko fluids are between -30 and $+15 \%$ and -6 to $+4 \%$, respectively. Comparison of the isotopic and chemical compositions of these fluids, as estimated from fluid inclusion data and oxygen isotopic data in quartz from siliceous ore, with those of pore fluids in the Deep Sea Drilling Project core samples has led to a metal-leaching model of continuous interactions between pore fluids (seawater) and volcanic rocks from the diagenetic through hydrothermal stages.

The delta $D$ and ${ }^{18} 0$ values of Kuroko fluids, values estimated from carefully selected data of Pisutha-Arnond and Ohmoto (1983), fall in the range between the fields of magmatic fluids and seawater (standard mean ocean water, SMOW) (fig. 5). The estimated delta D and ${ }^{18} 0$ values of fluids that formed sericite in the wall-rock alteration halo around the siliceous ores of the Kosaka deposits (Hattori and Muehlenbachs, 1980) fall in the range between the fields of the Kuroko fluids and seawater. Furthermore, delta $D$ and ${ }^{18} 0$ values of the hydrothermal fluids for kaolinite, which formed in the waning stage of mineralization, fall in the range between the fluids for sericite and seawater (Marumo, 1989). These data indicate that the magmatic fluids were a vital component for the mineralization and footwall alteration. The hydrothermal fluids that formed the Kuroko deposits had a richer magmatic fluid component than did the fluids responsible for the footwall sericite alteration, and the hydrothermal fluids were dominated by seawater during the waning kaolinite mineralization stage.

\section{Comparison with active sea-floor hydrothermal systems}

In the northeastern Pacific Ocean, sea-floor hydrothermal deposits and black smokers have been observed. Among these deposits, massive sulfides in the highly sedimented Middle Valley have higher $\mathrm{Pb} / \mathrm{Zn}$ ratios (up to 0.02 ) than those in other poorly sedimented rifts, such as those of the Axial Seamount and the southern Juan de Fuca Ridge (Kappel and Franklin, 1989). This finding indicates that lead in the Middle Valley was leached from the lead-rich sediments by ascending fluids.

The average lead content, however, in sulfide samples from the Middle Valley is only 0.05 percent, which is far smaller with respect to the lead contents of Kuroko deposits. The Kuroko-type sea-floor massive sulfide deposits (JADE, Japan-Deutche) in the Okinawa Trough (Halbach and others, 1989) are far more rich in lead (up to 25 percent) in comparison to those of the Middle Valley. This is due mainly to the difference in magma type (rhyolitic versus basaltic magma), which is controlled by the geological setting (presence or absence of continental crust).

The JADE deposits (fig. 1) provide advantageous evidence for the magmatic hydrothermal model. These deposits occur on the

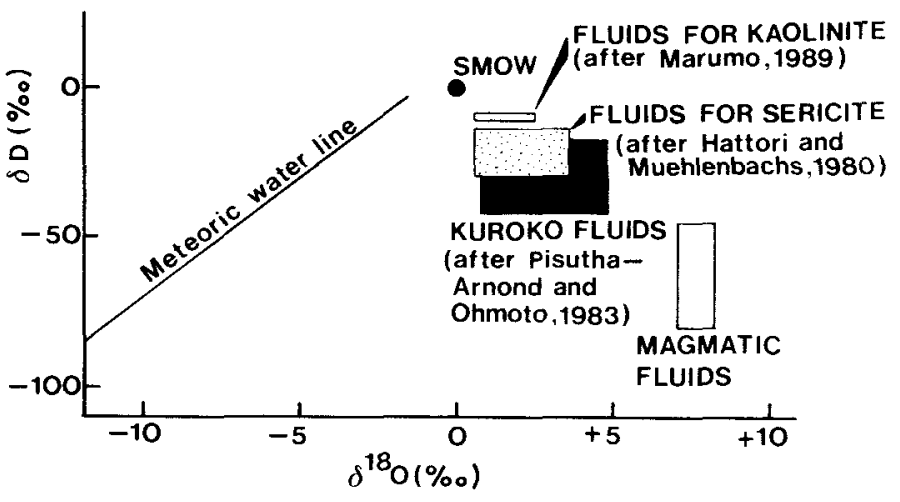

Figure 5. - Hydrogen $(\delta D)$ and oxygen $\left(\delta^{18} 0\right)$ isotopic compositions of the Kuroko ore fluids, as well as the fluids for sericite and kaolinite formation in the alteration halos, in comparison with SMOW (standard mean ocean water) and magmatic fluids. Only those samples that were analyzed for both $\delta D$ and $\delta^{18} 0$ are included in this figure.

northeastern slope of a tectonic depression called the Izena cauldron ( $5 \times 3 \mathrm{~km}$ in diameter). The JADE deposits consist of an inner massive sulfide zone and an outer barite-native sulfur zone, which together have a dimension of $500 \times 200 \mathrm{~m}$. The area of the inner massive sulfide zone corresponds to the area of a high heat flow zone $\left(>10,000 \mathrm{~mW} / \mathrm{m}^{2}\right)$, which is elongated northeast-southwest and indicates the presence of a high-level magma reservoir beneath the deposits (Urabe and others, 1990).

The inner massive sulfide zone is composed of active and fossil sulfide-sulfate chimneys and mounds that are located at depths between 1,300 and $1,550 \mathrm{~m}$. Among these chimneys, one black smoker discharges hydrothermal fluid that has a temperature of $320^{\circ} \mathrm{C}$. This fluid contains $200 \mathrm{mmol} \mathrm{CO}_{2}, 12.4 \mathrm{mmol} \mathrm{H}_{2} \mathrm{~S}$, and $14.8 \mathrm{mmol}$ $\mathrm{CH}_{4}+\mathrm{H}_{2}$ per kilogram of water. The gas content of the fluid is about 50 to 100 times that of the hydrothermal fluids at mid-ocean ridge spreading centers. The carbon and oxygen isotopic compositions of $\mathrm{CO}_{2}$ suggest that the gas was released from acidic magma (Sakai and others, 1990). The potassium-rich nature of the JADE fluids (up to $72 \mathrm{ppm}$ ) is characteristic of hydrothermal fluids that are formed by the reaction between seawater and volcanic rocks of acidic to intermediate composition. The fact that dacite lava domes are found on the sea floor of the Izena cauldron indicates the presence of the acidic magma.

\section{Revision of the magmatic hydrothermal model and its implication for Kuroko exploration}

The geological, geochemical, and geophysical data of the Kuroko deposits and their modern analog (JADE) in the Okinawa Trough indicate that a high-level reservoir of aluminous acidic magma is the major source of metal for the Kuroko deposits. However, the lead isotopic study and $\mathrm{Pb} / \mathrm{Zn}$ ratios in deposits of the northeastern Pacific Ocean indicate that some lead, as well as other metals such as barium and zinc, came from the wall rock through a leaching process.

In the revised magmatic hydrothermal model, the temperature of mineralization reaches its maximum immediately after the intrusion of the acidic magma (fig. 6). The magmatic fluid can carry enough copper to precipitate copper-rich ores (yellow ores) on the sea floor. 

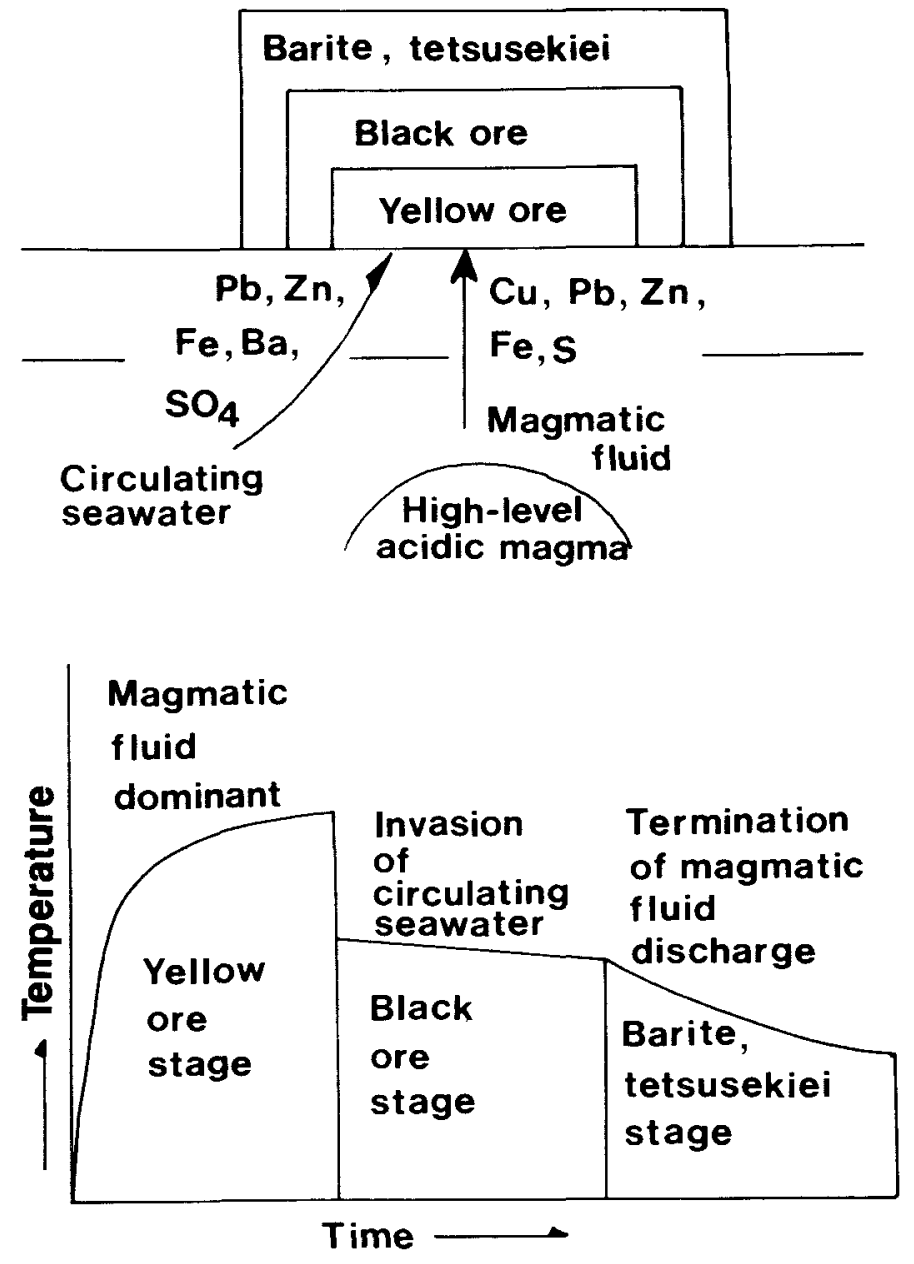

Figure 6. - Schematic illustration of the revised magmatic hydrothermal model.

Because the lead in the yellow ores came mainly from the acidic nagma, the lead isotopic compositions of the ore lead should repreient that of the magma and should also be similar to those of the middle Miocene volcanic rocks, which originated from the same acidic magma source. At the same time, the acidic magma heated the wall rocks by conduction and then generated the hydrothermal convection system that moved pore fluid in the wall rocks approximately a few hundred years later (Cathles, 1983). The heated pore fluid leached ore metals from the wall rocks and carried them along the paths of the convection system.

In the next stage, the circulating pore fluid invaded the magmatic discharge system and mixed with the magmatic fluid. The invasion of the pore fluid caused a drop in the temperature of the magmatic fluid and also caused a decrease in the ability of the magmatic fluid to carry copper to the site of deposition. Thus, the mixed fluids (magmatic fluid plus heated pore fluid) formed black ores when they mixed with the seawater on the sea floor. Because some lead in the black ore came from the basement rocks as well, the lead isotopic compositions of the black ores should be different from those of the yellow ores.

After the discharge of magmatic fluid ceased, the temperature of the hydrothermal fluid decreased drastically. The hydrothermal fluid, now dominant in pore fluid, had no potential to carry enough lead and zinc to form black ores. The mineralization of this next stage is characterized by the formation of barite and hematite and quartz beds on the black ores. The hydrothermal system of the Sumisu rift (fig. 1) in the Izu-Bonin arc (Urabe and Kusakabe, 1990) could be the present-day example of this stage.

\section{References}

Cathles, L.M., 1983, An analysis of the hydrothermal system responsible for massive sulfide deposition in the Hokuroku basin of Japan, in Ohmoto, H., and Skinner, B.J., eds., The kuroko and related volcanic massive sulfide deposits: Economic Geology Monograph 5, p. $439-487$.

Date, J., Watanabe, Y., and Saeki, Y., 1983, Zonal alteration around the Fukazawa kuroko deposits, Akita Prefecture, northern Japan, in Ohmoto, H., and Skinner, B.J., eds., The kuroko and related volcanic massive sulfide deposits: Economic Geology Monograph 5, p. 365-386.

Fehn, U., Doe, B.R., and Delevaux, M.H., 1983, The distribution of lead isotopes and the origin of kuroko ore deposits in the Hokuroku district, Japan, in Ohmoto, H., and Skinner, B.J., eds., The kuroko and related volcanic massive sulfide deposits: Economic Geology Monograph 5, p. $488-506$.

Halbach, P., Nakamura, K., and others, 1989, Probable modern analogue of Kuroko-type massive sulphide deposits in the Okinawa Trough backarc basin: Nature, v. 338, p. 496-499.

Hattori, K., and Muehlenbachs, K., 1980, Marine hydrothermal alteration at a Kuroko ore deposit, Kosaka, Japan: Contributions to Mineralogy and Petrology, v. 74, p. 285-292.

Ishihara, S., and Sasaki, A., 1978, Sulfur of Kuroko deposits-A deep seated origin?: Mining Geology, v. 28, p. 361-367.

Kajiwara, Y., 1971, Sulfur isotope study of the Kuroko-ores of the Shakanai No. 11 deposits, Akita Prefecture, Japan: Geochemical Journal, v. 4, p. 157-181.

Kappel, E.S., and Franklin, J.M., 1989, Relationships between geologic development of ridge crests and sulfide deposits in the northeast Pacific Ocean: Economic Geology, v. 84, p. 485-505.

Marumo, K., 1989, Genesis of kaolin and pyrophyllite of the Kuroko deposits of Japan: Mineralogical and geochemical studies: Geochimica et Cosmochimica Acta, v. 53, p. 2915-2924.

Nakajima, T., and Sasaki, A., 1985, Sulfur isotopic ratio and pyrite/ magnetite distribution in the Kuroko host rocks: Mining Geology, v. 35, p. 273-287. [In Japanese, English abstract.]

Nakano, T., and Urabe, T., 1989, Calculated compositions of fluids released from a crystallizing granitic melt: Importance of pressure on the genesis of ore forming fluid: Geochemical Journal, v. 23, p. $307-319$.

Ohmoto, H., Mizukami, M., Drummond, S.E., Eldridge, C.S., PisuthaAmond, V., and Lenagh, T.C., 1983, Chemical processes of kuroko formation, in Ohmoto, H., and Skinner, B.J., eds., The kuroko and related volcanic massive sulfide deposits: Economic Geology Monograph 5, p. 570-604.

Otofuji, Y., Matsuda, T., and Nohda, S., 1985, Paleomagnetic evidence for the Miocene counter-clockwise rotation of Northeast Japan: Rifting process of the Japan arc: Earth and Planetary Science Letters, v. 75 , p. $265-277$.

Pisutha-Amond. V., and Ohmoto, H., 1983, Thermal history, and chemical and isotopic compositions of the ore-forming fluids responsible for the kuroko massive sulfide deposits in the Hokuroku district of Japan, in Ohmoto, H., and Skinner, B.J., eds., The kuroko and related volcanic massive sulfide deposits: Economic Geology Monograph 5, p. 523-558.

Sakai, H., Gamo, T., Kim, E.-S., Tsutsumi, M., Tanaka, T., Ishibashi, J., Wakita, H., Yamano, M., and Oomori, T., 1990, Venting of carbon dioxide-rich fluid and hydrate formation in mid-Okinawa Trough backarc basin: Science, v. 248, p. 1093-1096.

Tanimura, S., Date, J., Takahashi, T., and Ohmoto, H., 1983, Geologic setting of the kuroko deposits, Japan; Part II, Stratigraphy and structure of the Hokuroku district, in Ohmoto, H., and Skinner, B.J., eds., The kuroko and related volcanic massive sulfide deposits: Economic Geology Monograph 5, p. 24-39. 
Urabe, T., 1985, Aluminous granite as a source magma of hydrothermal ore deposits: An experimental study: Economic Geology, v. 80 , p. $148-157$.

-1987a, Kuroko deposit modeling based on magmatic hydrothermal theory: Mining Geology, v. 37, p. 159-175.

$-1987 \mathrm{~b}$. The effect of pressure on the partitioning ratios of lead and zinc between vapor and rhyolite melts: Economic Geology, v. 82 , p. 1049-1052.

Urabe, T., and Kusakabe, M., 1990, Barite silica chimneys from the Sumisu Rift, Izu-Bonin Arc: Possible analog to hematitic chert associated with Kuroko deposits: Earth and Planetary Science Letters, v. 100 , p. $283-290$

Urabe, T., Marumo, K., and Nakamura, K., 1990, Mineralization and related hydrothermal alteration in Izena Cauldron (JADE site), Okinawa Trough, Japan [abs.]: Geological Society of America Abstracts with Programs, v. 22, p. A9-10.

Yamaji, A., 1990, Rapid intra-arc rifting in Miocene northeast Japan: Tectonics, v. 9 , p. $365-378$.

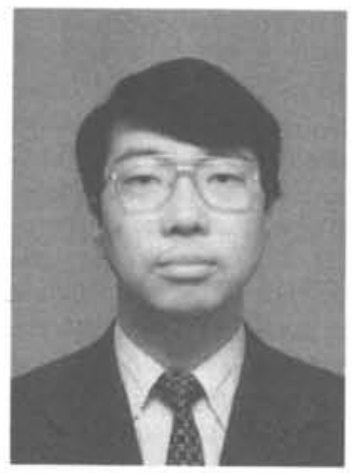

Dr. Tetsuro Urabe received his doctorate in geology from the University of Tokyo in 1976, where he was an Assistant Professor (joshu) until 1985. He was at the University of Toronto in Canada between 1979 and 1981 as a visiting researcher and was involved in research on massive sulfide deposits in the Canadian Shield and Canadian Cordillera. He went to the Geological Survey of Japan in 1985 and started sea-floor hydrothermal studies in western Pacific areas, including the Izu-Bonin arc, Okinawa Trough, and North Fiji Basin. His research interests also include highpressure experiments on the granitewater-metal chloride system.

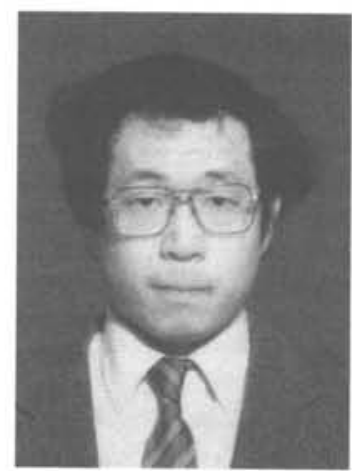

Dr. Katsumi Marumo studied geochemistry and mineralogy at Nagoya University, where he submitted in 1989 his doctoral thesis entitled "Genesis of Kaolin Minerals and Py. rophyllite in Kuroko Deposits of Japan: Implications for the Origins of the Hydrothermal Fluids From Mineralogical and Stable Isotope Data." He is now a Senior Researcher at the Geological Survey of Japan. His main research interests include the comparison of mineralogy and geochemistry of hydrothermal systems among the Okinawa Trough, the northeastern Pacific spreading centers, and the Kuroko and Besshi-type deposits. 